\title{
The TELA: A New Tool for Assessing Educator Environmental Literacy
}

\author{
Roberta H. Hunter ${ }^{1 *}$, Rebecca C. Jordan ${ }^{2}$
}

\begin{abstract}
${ }^{1}$ Graduate School of Education, Rutgers University, USA
${ }^{2}$ Department of Community Sustainability, Michigan State University, USA

*Corresponding Author: robertahhunter@gmail.com
\end{abstract}

Citation: Hunter, R. H., \& Jordan, R. C. (2019). The TELA: A New Tool for Assessing Educator Environmental Literacy. Interdisciplinary Journal of Environmental and Science Education, 15(1), e02201. https://doi.org/10.29333/ijese/6286

\section{ARTICLE INFO}

Received: 12 Nov. 2019

Revised: 19 Nov. 2019

Accepted: 19 Nov. 2019

\begin{abstract}
This paper describes the measurement and outcomes of a novel teacher environmental literacy assessment. The Teacher Environmental Literacy Assessment (TELA) uses a contextual view of environmental literacy, and includes measures of Knowledge, Self-efficacy, Environmental Identity, Behavior, Issue Identification, and Strategy Selection. A sample of formal and nonformal educators and experts were selected to take and be interviewed about TELA responses. We found demographic differences, particularly between nonformal and formal educators. In addition, experts chose different types of strategies to address environmental issues than educators. The TELA can identify gaps in educator environmental literacy, which is vital content knowledge for educators.
\end{abstract}

Keywords: environmental literacy, teachers, educators, assessment

\section{INTRODUCTION}

Though environmental education has been formalized for 50 years (Stapp, 1969), we still struggle as a society with developing in our students a strong level of environmental literacy. Roth (1968) proposed “environmental literate” to mean those that acted positively towards the environment, in contrast to the phrase "environmentally illiterate" used in the media. More modern definitions, such as Hollweg, et al. (2011) provide a more nuanced approach, taking into account the environmental education goals that emerged from the 1977 UNESCO Intergovernmental Conference on Environmental Education, held in Tbilisi, Russia. The conference was convened to address the role of education in addressing environmental issues and create a plan of action. The Tbilisi Declaration (UNESCO, 1977) proposed:

○ to foster clear awareness of, and concern about, economic, social, political, and ecological interdependence in urban and rural areas;

$\bigcirc \quad$ to provide every person with opportunities to acquire the knowledge, values, attitudes, commitment, and skills needed to protect and improve the environment;

$\circ$ to create new patterns of behavior of individuals, groups, and society as a whole towards the environment.
Given continuing and emergent environmental issues, the pressure is greater than ever to create citizens that are environmentally literate in a way that fits into a highly mobile, information saturated world. There is a need for both youth and adults that are knowledgeable of biophysical and social systems, who understand the integration of social and environmental components of environmental issues, and who have attitudes that benefit the environment and people, and who can identify issues and engage in investigation, evaluation and action on the best solutions in a given context; that is who are environmentally literate. Without a citizenry that is so prepared, people in the U.S. and beyond will be unable to engage with the environment in a sustainable way, threatening the stability of both human and ecological systems.

This paper will describe the development and use of a new instrument for the assessment of environmental literacy in educators, with an eye towards ensuring that educators are well prepared to work towards those goals.

\section{TEACHER ENVIRONMENTAL LITERACY}

If environmental literacy (EL) is necessary to address existing and emergent issues, then it would seem desirable for all students to be exposed to high quality EE that improves their EL. Knowing the importance of teacher content 
knowledge (Ball et al., 2008; Shulman, 1986) - the content of a domain, including the structure of that knowledge, epistemological issues of what is expertise, and what holds as warrants - we must turn our attention to the EL of teachers. I argue that teacher environmental literacy can be seen as necessary content knowledge. For those educators who teach content that addresses environmental issues, such as environmental science or geography, we should expect not only a knowledge of ecological science, but also a knowledge of the social components of issues, knowledge of and ability to engage with and address issues, and a generally positive disposition towards the environment - that is, a certain level of environmental literacy.

Environmental literacy has been studied at multiple ages, including K-12 students (McBeth, et al., 2008; Ozsoy, Ertepinar, \& Saglam, 2012; Saltan \& Divarci, 2017; Stevenson, et al., 2013), university students (S. Hsu, 2004; Kaplowitz \& Levine, 2005; Lloyd-Strovas, Moseley, \& Arsuffi, 2018), and adults (Coyle, 2005). Which elements are studied as environmental literacy varies, though the most common components are knowledge, dispositions, and behavior (see Genc \& Akilli (2016) for a concise summary). Practices such as issue identification, planning action to address issues, and evaluating action choices are regularly left out of studies, with noticeable exceptions of the Middle School Environmental Literacy Survey (MSELS; Erdogan \& Ok, 2011; McBeth, et al., 2008; Stevenson, et al., 2013) and a handful of others inspired by the MSELS (Negev, et al., 2008; Shin, et al., 2005).

There is a limited research body regarding teacher EL, and even less in the United States. This leaves a gap in the research body - what is the state of teachers' EL practices? One challenge in comparing teachers across studies is that each study uses its own framework for EL, including or excluding different facets. While none of the literature explicitly addresses skills or practices, which are central to this study, there are some commonalities: knowledge, dispositions, and behavior.

There are multiple types of knowledge, however, in the limited teacher EL literature - background content knowledge (environmental science, biology, geology, etc.), knowledge of issues, knowledge of action strategies, and perceived knowledge of any of those. In an extensive study of secondary teachers in Taiwan, Hsu and Roth (1998) focused on teachers' perceived knowledge of content, issues, and strategies. They found that teachers had limited knowledge of strategies, but felt moderately confident in their knowledge of ecology, environmental science, and issues. Liu et al. (2015) also looked at national data for Taiwan teachers and found moderate levels of knowledge. Swanepoel, Loubser, and Chacko (2002), working with teachers in South Africa, found that teachers who taught natural sciences scored better on their assessment as a whole, but environmental-themed professional development did not increase knowledge scores. In work with Australian primary teachers using Orr's (1992) definition of EL, CutterMackenzie and Smith (2001) found that most of the teachers were environmentally illiterate or at a nominal level of EL little knowledge, and not contextualized.

Hsu and Roth (1998) included several dispositions (environmental sensitivity, attitudes, responsibility, locus of control, and intention to act) in their work. Teachers had positive attitudes, high sensitivity, and moderate self-efficacy. Cheng and So (2015) studied the EL of primary school teachers in Hong Kong. The authors conclude that individual background, motivation, and teaching are closely connected, with individual commitment being the most important factor. In Swanepoel, et al. (2002), environmental professional development did seem to lead to higher awareness, attitude, and willingness to participate in actions.

Liu et al. (2015) found low levels of environmental behavior in their participants. Hsu and Roth (1998) examined how different scales related to behavior score, and found the best predictors were environmental responsibility, perceived knowledge of strategies, attitudes, and place of residence with urban areas reporting more environmental action than rural areas.

Though limited, the research on teacher EL suggests a complex interplay of dispositions, knowledge, demographic factors, and behavior. The goal of the research described in this paper is to examine teacher EL in the U.S. using a novel instrument, the Teacher Environmental Literacy Assessment, which aligns with a contextual perspective on EL.

\section{ENVIRONMENTAL LITERACY}

Environmental literacy (EL), first described 50 years ago (Roth, 1969) has changed conceptually over time, while still hewing to its roots. For many years, it was considered to be synonymous with the objectives of environmental education (EE), such as the Tbilisi goals (UNESCO, 1977). Volk and colleagues (1984) describe EL in a critique of EE, which they stated was "...failing in its endeavor to develop knowledgeable, concerned, competent, and participating citizens, i.e., environmentally literate human beings.” (p. 12) Marcinkowski (1991) fleshed out the concept, including ideas of environmental issue scale, as well as the interface of natural and socials systems. Beginning in the early 1990's, frameworks for EL turned an eye towards its assessment. For example, Roth (1992) revisited his earlier work, outlining four strands of EL: knowledge, skills, affect, and behavior. Later, Stables (1998) took more critical readings of EL, describing a continuum. Stables (1998) describes the levels as functional (knowledge of things in the environment and the ability to identify what is not known), cultural (knowledge of the cultural and social roles of the natural world and human impacts on them), and critical (the ability and willingness to engage with deeper meanings of the environment and society, and use that to address issues, pushing back against hegemony). Stables does note that these levels build on each other, and that "both cultural and critical literacy are impossible without functional literacy. Just as the ability to decode print is a prerequisite to the development of deeper levels of comprehension of the passage to be read, so is knowledge of the natural world a condition of the development of awareness of environmental issues and of the ability to take effective action.” (p. 158) Stables' ideas, particularly that of critical environmental literacy, have not been largely taken up in EE research, even as it has grown to include critical frameworks such as place-based education and indigenous voices. Emphasis has been placed on frameworks that are more easily assessed. 
A more recent project, targeted for the assessment of EL, was published by the North American Association for Environmental Education (Hollweg et al., 2011). It synthesizes previous work and creates a framework composed of dispositions, knowledge, competencies, and environmentally responsible behavior practiced in multiple contexts. While the Hollweg et al.'s work does describe the importance of socialpolitical and ecological knowledge, it does not include the notion of a gradation of literacy, nor the changing engagement with the environment with an advancing literacy. While Stables' work is theoretical and does not address how to get to this higher level of literacy, Hollweg et al. (2011) is explicitly practical, framing what can and should be assessed.

\section{THE CONTEXTUAL VIEW OF ENVIRONMENTAL LITERACY}

The research described here takes a contextual view of EL. EL is seen as multi-faceted and existing on a continuum of how one engages with the environment and information about the environment. It departs from earlier frameworks, however, by explicitly perceiving environmental literacy as contextual and situated in social-ecological systems (Berkes and Folke, 1998), bringing to the forefront the social nature of literacy that Hollweg and colleagues (2011) include in the background. There is no absolute level of environmental literacy, rather degrees of practice in engaging with social-ecological systems.

As with previous framings of EL, the contextual view includes knowledge of biophysical and sociocultural systems, representing the entangled nature of social-ecological systems. Though there are cross-contextual components of biophysical and social knowledge, such as ecological processes (i.e. photosynthesis, carbon cycling) and systems fundamentals (i.e. feedback loops, emergence), and possible avenues of action on issues, much of it is dependent on the social-ecological context an individual is in, opening EL up to multiple ways of knowing a system.

Dispositions include environmental self-efficacy, one's perception of inclusion with nature (Schultz, 2002), and environmental identity (Kempton \& Holland, 2003). Behavior is viewed as participation in multiple avenues of responsible environmental behavior, using the categories of ecomanagement, consumer, persuasive, political and legal action (Hungerford \& Tomera, 1977).

The contextual framing departs through the perception of issue identification and action planning as practices rather than skills, emphasizing the social and embedded nature of both. Because EL is situated and on a continuum of engagement, we use the theory of situated learning (Lave \& Wenger, 1991) and work on communities of practice (Wenger, 1999) and legitimate peripheral participation (Lave \& Wenger, 1991). From this perspective, individuals who are becoming aware of the environment and building a functional level of EL are entering into legitimate peripheral participation in the community of environmentally responsible citizens. While these newcomers are not yet experts, they are members of the community, and with experience and the attendant learning move towards expert status. Experts are those who have experience, who have robust practices and deep knowledge who have been shown to be effective in the solving or descriptions about solving critical environmental issues. As newcomers increase knowledge and develop practices common to the community (such as issue identification and analysis, generation and evaluation of solutions, and action, referred to here as EL practices), their participation becomes more central, their identity shifts, and they progress along the continuum described by Stables (1998). In an EL context, experts have an understanding of social-ecological systems, and they are experienced at identifying issues and promising paths to address them. This legitimate peripheral participation framework aligns with Kempton and Holland's (2003) model of environmental identity. They describe three stages of social environmental identity, from becoming aware of issues (salience), to acting on issues and seeing oneself as an actor, and developing a knowledge base of how to effectively engage in environmental practices.

\section{RESARCH QUESTION}

This paper describes the use of the Teacher Environmental Literacy Assessment (TELA), which uses the contextual perspective to assess the environmental literacy of formal and nonformal educators. In particular, we look at demographic effects, educational background, and institutional setting, and how educators compare to experts. We expect that nonformal educators will have higher EL, as will those in the life and environmental sciences, and experts will approach environmental issues differently.

\section{METHODS}

\section{Instrument}

The TELA was developed using the contextual view of EL as a guiding framework. In alignment with the contextual framework of EL, seven scales were developed in addition to collecting demographic information:

- Knowledge - Twenty items (multiple-choice and open-response), including from the NEETF/Roper scale (Coyle, 2005), with additional questions embedded in the scenarios described below.

- $\quad$ Self-efficacy - A novel scale using a seven-point Likert-type scale addressing individual and collaborative efficacy on environmental issues.

- Connection to the environment - The graphical Inclusion of Nature in Self measure (Schultz, 2002) determines the extent to which respondents see nature and themselves overlapping, an essential component of the social-ecological systems used in this framework.

- Environmental identity - Novel five-point Likerttype scale based on three aspects of identity development from Kempton and Holland (2003).

- Behavior - Open-ended questions to solicit respondent behaviors, in five categories (Hungerford, \& Tomera, 1977). Three categories are personal-level action: ecomanagement, persuasive, and consumer actions; two are at 
Table 1. Gender, race, and ethnicity of TELA formal sample (\%) and U.S. teaching population

\begin{tabular}{lcc}
\hline & TELA & $\begin{array}{c}\text { U.S. Public teaching } \\
\text { (2015-16; IES-NCES) }\end{array}$ \\
\hline Gender & & \\
\hline Female & 76.8 & 64 \\
\hline Male & 21.3 & 36 \\
\hline $\begin{array}{l}\text { Other (incudes neither and } \\
\text { prefer not to say) }\end{array}$ & 1.5 & Not included \\
\hline Race & & \\
\hline White & 75.4 & 80 \\
\hline Black/African American & 12.8 & 7 \\
\hline Asian-American/Pacific Islander & 3.8 & 2 \\
\hline American Indian/Alaska Native & 0 & $0 *$ \\
\hline Other/More than one & 8.1 & 9 \\
\hline Ethnicity & & \\
\hline Hispanic & 12.3 & \\
\hline < l\% & & \\
\hline
\end{tabular}

a systemic level: political and legal actions. Allowing for a variety of behaviors in multiple categories is fitting for issues in different contexts. It also addresses some issues with environmental behavior scales raised by Olson (1981) - with maximum scores in each category, a high score is not possible through low-impact personal sphere behaviors alone.

- $\quad$ Finally, three scenarios were constructed, similar to those used with the MSELS (McBeth, et al., 2008), to assess practices. Scenarios involving common environmental issues (changes in land use, the siting of an industrial waste facility, and logging/species conservation) yield two scores: Issue Identification and Strategy Selection. Respondents' top two choices of issue and strategy (from the five used in the Behavior scale) are compared to those of experts from nonprofits, academia, and state environmental agencies.

- $\quad$ Personal and teaching demographics (instructional setting, grade level, and subject taught), are collected at the end of the instrument.

The initial pilot of TELA was as a pre-post assessment for a professional development program. Additional piloting, including with small focus groups, occurred in fall of 2017. Initial analysis showed a high correlation between the environmental identity and self-efficacy scales. Those scales were modified and tested with another small group, which found that the scales were no longer highly correlated. In January 2018, the scenarios were sent to six experts from academia, state environmental agencies, and environmental non-profits in New Jersey, to determine what the expert responses are in a New Jersey context. These were used in scoring the TELA in the broader testing.

\section{Participants}

Respondents to the online TELA survey came from two sources. Qualtrix recruited K-12 teachers from the U.S $(n=100)$, with special effort towards a diverse sample. Additional respondents $(n=160)$ were recruited through a combination of convenience and snowball sampling. Recruitment notices were sent via email, listserv, and social media to colleagues in formal and nonformal education settings, who then shared with their professional circles. A subsample of respondents ( 25 formal, 25 nonformal) also completed interviews to validate the instrument and explore responses more deeply.
Table 2. Race and ethnicity of the TELA nonformal sample (\%) and U.S. EE population

\begin{tabular}{lcc}
\hline & TELA & $\begin{array}{c}\text { U.S. EE teaching } \\
\text { population (Gupta et } \\
\text { al., 2015) }\end{array}$ \\
\hline Race & & \\
\hline White & 86.7 & 53.8 \\
\hline Black/African American & 4.4 & 19.5 \\
\hline Asian-American / Pacific Islander & 4.4 & 1.0 \\
\hline American Indian / Alaska Native & 0 & 3.1 \\
\hline Other/More than one & 4.4 & 6.0 \\
\hline Ethnicity & & \\
\hline Hispanic & 11.9 & $32.6^{*}$ \\
\hline
\end{tabular}

*Percentage of environmental educators in EPA Region 2, which includes NJ. Information for overall sample was not included.

The formal educator respondent sample was representative of the U.S. national teaching force (Table 1) in gender, race, and ethnicity, though it slightly over-represents racial and ethnic minority groups. The sample was representative in terms of higher education, with $54.3 \%$ having postbaccalaureate education, compared to the national figures of $55 \%$ for elementary teachers and $59 \%$ for secondary. For nonformal educators (Table 2), the sample slightly underrepresented minorities according to demographics by Gupta et al. (2018). No information is available for gender or educational attainment for nonformal environmental educators, but in the sample, $48.9 \%$ had a bachelors, and $18.4 \%$ had post-baccalaureate education. In the overall TELA sample, $13.8 \%$ reported they were financially struggling, 50.4\% were stable, $33.8 \%$ were comfortable, and $1.9 \%$ were affluent.

\section{RESULTS}

\section{Instrument Scales}

The descriptive statistics for the scales are presented in Table 3. Self-efficacy and Environmental Identity are both negatively skewed, which can be accounted for by possible self-selecting error in the sample. In addition, crosscorrelations were calculated for the seven scales (Table 4).

\section{Knowledge}

Knowledge and Behavior scores were highly correlated $(0.728 ; p<0.01)$. Knowledge is also highly correlated (0.562) with Issue Identification and moderately correlated with Strategy Selection (0.380), all $p<0.01$.

\section{Environmental identity}

Environmental Identity was moderately correlated $(p<0.01)$ with Knowledge (0.475), and highly correlated with SelfEfficacy (0.534), INS (0.522), and Behavior (0.541).

\section{Demographic effects}

The TELA also included personal demographics (e.g. race/ethnicity, gender, perceived financial status, residence, level of education) and instructional demographics (e.g. setting, grade taught, and subject taught). An exploratory analysis of demographic effects on the TELA scales showed several interesting patterns around race/ethnicity, 
Table 3. Descriptive statistics for TELA scales

\begin{tabular}{|c|c|c|c|c|c|c|}
\hline & Score range & Min & Max & Mean & Std. Deviation & Cronbach's alpha \\
\hline Knowledge & $0-24$ & 2 & 21 & 13.19 & 4.37 & .778 \\
\hline Self-efficacy & $4-28$ & 4 & 28 & 23.50 & 4.02 & .837 \\
\hline INS & $1-7$ & 1 & 7 & 4.78 & 1.39 & $\mathrm{~N} / \mathrm{A}$ \\
\hline Environmental Identity & $8-40$ & 16 & 40 & 35.16 & 5.38 & .903 \\
\hline Behavior & $0-15$ & 0 & 13 & 4.87 & 3.16 & $\mathrm{~N} / \mathrm{A}$ \\
\hline Issue Identification & $0-15$ & 0 & 15 & 8.80 & 2.96 & $\mathrm{~N} / \mathrm{A}$ \\
\hline Strategy Selection & $0-27$ & 4 & 24 & 15.00 & 4.39 & $\mathrm{~N} / \mathrm{A}$ \\
\hline
\end{tabular}

Table 4. Pearson's correlations for scales

\begin{tabular}{|c|c|c|c|c|c|c|c|}
\hline & Knowledge & Self-Efficacy & INS & $\begin{array}{c}\text { Environmenta } \\
1 \text { Identity }\end{array}$ & Behavior & $\begin{array}{c}\text { Issue } \\
\text { Identification } \\
\end{array}$ & $\begin{array}{c}\text { Strategy } \\
\text { Selection }\end{array}$ \\
\hline Knowledge & 1 & & & & & & \\
\hline Self-Efficacy & $0.167^{* * *}$ & 1 & & & & & \\
\hline INS & $0.323^{\text {*** }}$ & $0.371^{* * * *}$ & 1 & & & & \\
\hline Environmental Identity & $0.475^{* * *}$ & $0.534^{* * * *}$ & $0.522^{* * *}$ & 1 & & & \\
\hline Behavior & $0.728^{* * *}$ & $0.226^{* * *}$ & $0.365^{* * *}$ & $0.541^{* * * *}$ & 1 & & \\
\hline Issue Identification & $0.562^{* * *}$ & 0.012 & $0.132^{*}$ & $0.259^{\text {***** }}$ & $0.443^{\text {*** }}$ & 1 & \\
\hline Strategy Selection & $0.380^{* * *}$ & 0.100 & 0.101 & $0.166^{\text {*** }}$ & $0.379^{* * *}$ & $0.283^{* * * *}$ & 1 \\
\hline
\end{tabular}

*p $<.05 ; * * \mathrm{p}<.01$

instructional setting, and level of education. Tables of means are found in Appendix A.

\section{Gender}

The main effect found was that the category Other (responses of "Neither" and "Prefer not to say") scored significantly $(p<0.05)$ lower than women or men on Selfefficacy, INS, Environmental Identity, and Issue Identification. In addition, women scored significantly lower than men on Issue Identification.

\section{Race/Ethnicity}

Two patterns emerged in this analysis. First, Hispanics scored significantly $(p<0.05)$ lower than non-Hispanics on scales of Knowledge and Behavior. Secondly, Whites scored significantly higher than those identifying as Black/African American and Other/More than one (American Indian / Alaska Native [ $n=1$ ] was folded into this category for analysis purposes) on Knowledge and Behavior, higher than Black/African American on Issue Identification, and higher than Other on Self-efficacy and Environmental Identity.

\section{Educational attainment}

The highest level of education completed showed significant $(p<0.05)$ effects on four scales: Knowledge, Behavior, Issue Identification, and Strategy Selection. In general, lower levels of attainment (high school, Associates, or some college) scored significantly lower across scales than post-baccalaureate levels of education. In addition Bachelors scored significantly lower than Some Grad School and Masters on Knowledge and lower than some grad school on Issue Identification.

\section{Instructional setting and grade taught}

Respondents who worked in a nonformal setting scored higher $(p<0.05)$ than those in public, private, or afterschool settings on Knowledge and Behavior and higher than public or private on Environmental Identity and Issue Identification.
For grades taught, the respondents teaching K-12 scored significantly higher than those teaching K-2, 3-5, 6-8, or 9-12 on Knowledge, Behavior, Environmental Identity, and Issue Identification. Multiple grades up to and including sixth also scored higher than K-2, 3-5, 6-8, and 9-12 on Knowledge. Grades K-8 scored higher than K-2, 3-5, 6-8, 9-12, and multiple grades up to and including sixth on INS.

Issue Identification and Strategy Selection - Experts and Educators

Aligned with the contextual view of environmental literacy was the use of scenarios to assess the practices of issue identification and action strategy selection. While Issue Identification had significant differences in most demographics, Strategy Selection did not. However, when one compares the types of strategies chosen by the experts and educators, a pattern emerges. Experts chose systemic level variables $66.67 \%$ of the time, but educators only chose systemic level actions $45.02 \%$ of the time (Figure 1).

\section{EL Profile of the TELA Sample}

Scale scores were divided into Low, Moderate, and High ranges for comparability and compiled into a profile. The TELA sample profile using means is presented in Figure 2. Behavior falls in the Low range; Knowledge, INS, Issue Identification and Strategy Selection in the Moderate Range; and Selfefficacy and Environmental Identity in the High range.

\section{Principal Component Analysis}

A Principal Component Analysis was conducted on the TELA data after a Bartlett's Test of Sphericity indicated an adequate sample. The first two components explained $64.49 \%$ of the variance. Component 1 consisted of Knowledge, Behavior, Issue Identification and Strategy Selection, and Component 2 included the dispositions of Environmental Identity, Self-Efficacy, and INS (Table 5). This shows a relationship between the dispositional factors (component 2) as well as between practices, knowledge, and behavior. 


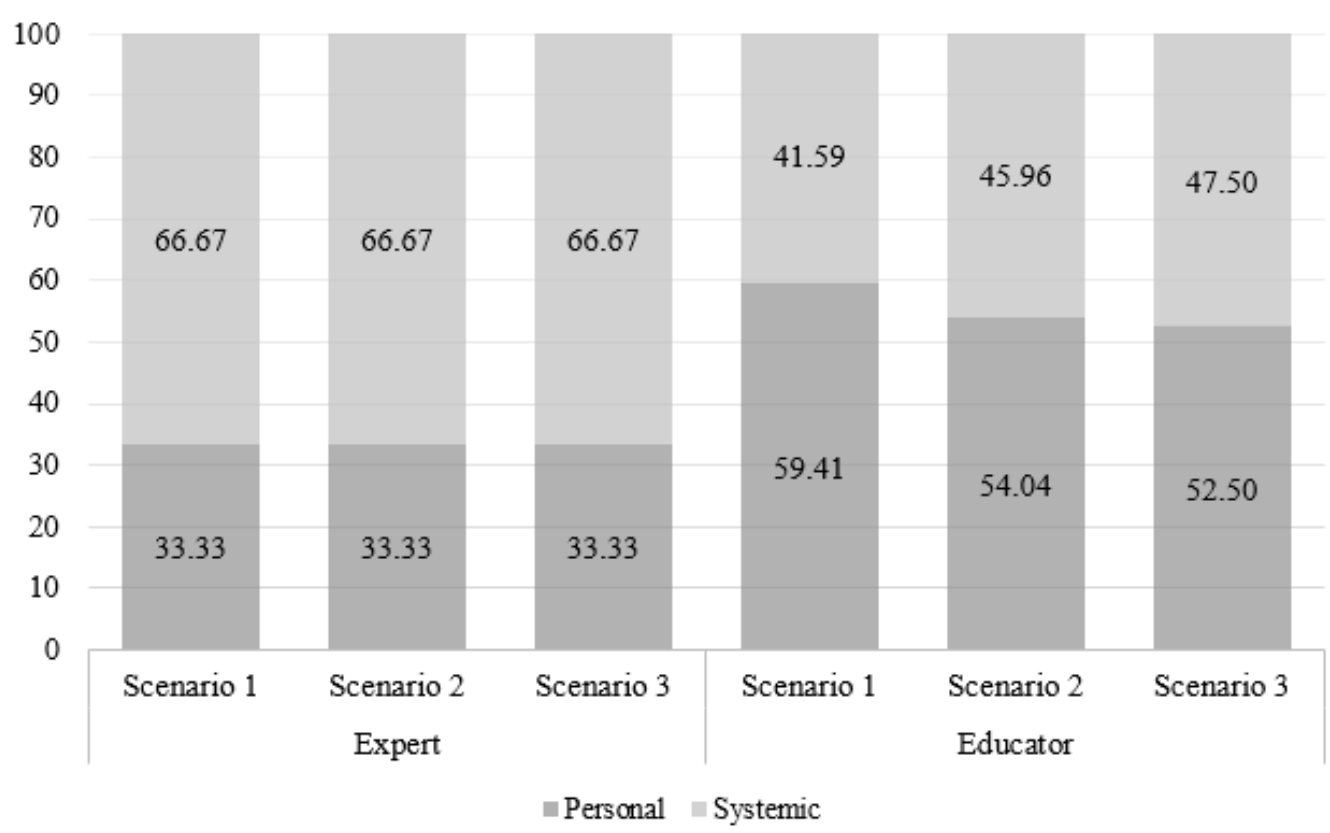

Figure 1. Percent of experts and educators choosing personal or systemic strategies

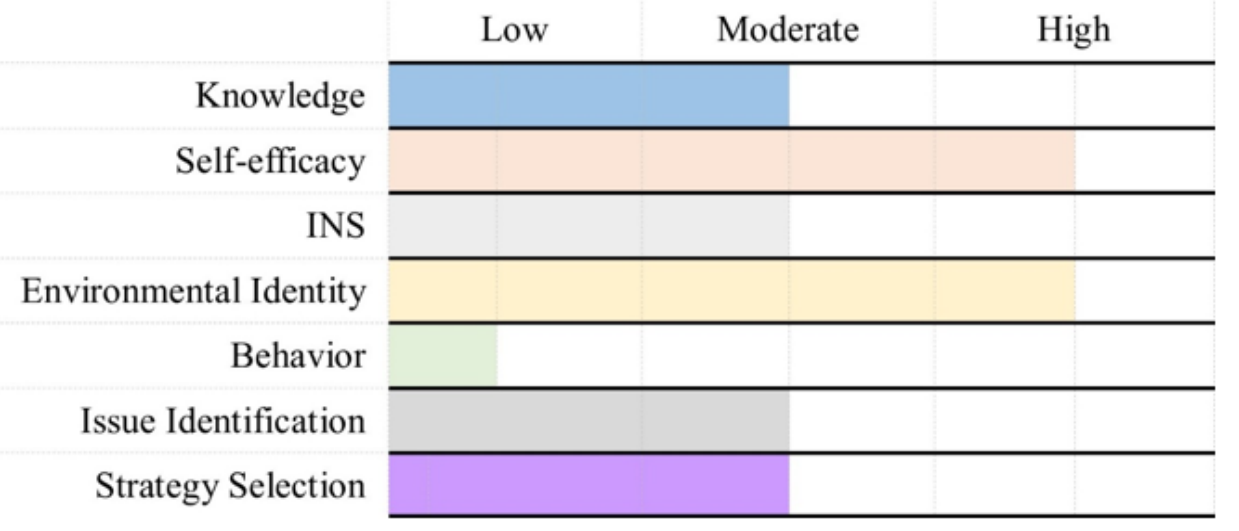

Figure 2. EL profile of the TELA sample, using sample means

Table 5. Principal Component Analysis of TELA Scales

\begin{tabular}{cll}
\hline Component & & \\
\hline \multirow{2}{*}{1} & Knowledge & 0.832 \\
\cline { 2 - 3 } & Issue Identification & 0.781 \\
\cline { 2 - 3 } & Behavior & 0.755 \\
\cline { 2 - 3 } & Strategy Selection & 0.628 \\
\hline \multirow{2}{*}{2} & Self-efficacy & 0.811 \\
\cline { 2 - 3 } & Environmental Identity & 0.805 \\
\cline { 2 - 3 } & INS & 0.747 \\
\hline
\end{tabular}

Extraction Method: Principal Component Analysis.

Rotation Method: Varimax with Kaiser Normalization, rotation converged in 3 iterations.

\section{DISCUSSION}

\section{Scale Correlations}

A strong correlation between Knowledge and Behavior is in line with some research (Genc \& Akilli, 2016; Murphy \& Olson, 2008), but contradicts other work (e.g. Fah \& Siresena, 2014; Liu et al., 2015; Pe'er et al., 2007). This higher correlation may be because of the wider scope of included behavior items, or because the Knowledge scale included both decontextualized multiple choice items and higher-level, contextualized items in which respondents answered within an environmental scenario, providing a more authentic assessment. In addition, Coyle (2005) and Murphy and Olson (2008) found that adults with high knowledge levels were more likely to engage in some behaviors: home energy saving, conserving water, donating to conservation groups, and avoiding toxic lawn chemicals.

Knowledge is also highly correlated with Issue Identification and moderately correlated with Strategy Selection. Knowledge of ecological systems and human impacts on them is necessary for being able to identify what in a scenario is likely to become an issue and what is a potentially productive strategy for addressing it. Some baseline level of knowledge is necessary for even a contextual environmental literacy, as Stables suggests that critical EL is not possible without a functional EL.

The high correlation between Behavior and Knowledge, and Behavior and Environmental Identity, along with its moderate correlation with INS support the Value-Belief-Norm theory of environmental behavior (Stern, 2000). This theory 
describes the importance of one's own sense of responsibility (evident in the Environmental Identity scale), and awareness of the potential impacts of an issue on something that has value (evident in the Knowledge and Environmental Issue scales), combined with an ecological worldview (INS) and personal moral norms to the enactment of environmentally significant behavior. This view does not preclude outside influences, such as social-ecological system factors that may inhibit or support environmental behavior.

Environmental Identity was moderately correlated with Knowledge, and highly correlated with Self-Efficacy, INS, and Behavior. Kempton and Holland's framework of environmental identity (2003) is based on a developing awareness of environmental issues (Knowledge), taking action on issues (Behavior), and an increasing capacity for environmental action (Self-Efficacy), suggesting that this novel scale reflects that framework.

\section{Demographic Effects}

The environmental field is an overwhelmingly White one (Taylor, 2018) and environmentalism is still often falsely perceived as a White endeavor (Greenberg, 2005; Person et al., 2018), excluding Blacks and other minorities at many levels. In addition, Blacks and some Hispanics have been found to score lower on behavioral measures than Whites (Johnson et al., 2004) which may explain the difference between Knowledge, Behavior, and Issue Identification scores.

Respondents who worked in nonformal settings and those teaching grades K-12 (14 of 17 work in nonformal settings) scored higher than those in other settings on Knowledge, Behavior, Environmental Identity, and Issue Identification. Research demonstrates that college major has an effect on environmental knowledge, attitudes, and beliefs (Goldman, Yavetz, \& Pe'er, 2014; Hodgkinson \& Innes, 2001; Tikka, Kuitunen, \& Tynys, 2000). Nonformal educators are more likely to have an environmental degree, and 1) have greater exposure to environmental content in their schooling; and 2) be working in settings with an environmentally aware and/or active social cohort, leading to potential peer effects on identity. These could include modelling of environmental behaviors or a professional need to stay abreast of environmental issues. In interviews, participants spoke of both discussing and learning about issues from peers and coworkers and of learning about environmental issues because the topics were in their curriculum.

\section{Lack of Systemic Actions}

The difference in strategy selection between educators and experts on strategy reflects previous work on reasoning about environmental issues such as climate change. Hart (2011) demonstrated that framing that emphasizes system-level effects (which experts would be knowledgeable about) led to greater preference for policy change rather than individual behavior. Chua (2016) found that experts thought about climate change on a greater time scale than students, which would lend itself to higher level solutions. Thinking about issues at systemic levels, and at greater time scales, could lead to choosing what Stern (2000) called "environmentally significant behaviors" over those with limited impact. This difference can be explained through a legitimate peripheral participation framework - that as people participate more fully in the community of environmentally active citizens, developing deeper knowledge, they begin to choose strategies that will have more effect on larger scales.

The majority of educators did not choose systemic actions to address environmental issues. In interviews, both formal and nonformal educators said they didn't feel it was their role to engage in political or legal action, or felt more comfortable taking personal action. Systemic action was usually limited to voting with environmental issues in mind. Some nonformal educators felt that persuading others to take issue was a natural extension of their job and life, while formal educators felt that it was in conflict with theirs. So the questions remains - how do we remove barriers to or increase comfort with systemic level actions?

\section{FUTURE WORK}

The TELA has helped us look at educator EL in a new light. With further study, it could be used with educators to assess their environmental literacy and identify areas for improvement, or used as a pre-post measure for professional development (Authors, in prep). To improve the quality of the TELA, Self-efficacy and Environmental Identity scales should be re-examined and tested with a more diverse sample to see if their skew is attributable to the instrument itself or selfselection effects.

With the TELA we have developed an instrument for assessing how environmentally literate educators are. Future research should begin to address how this environmental literacy is enacted in classroom practice. How do educators engage with environmental material in their instruction? What types of intervention improve different facets of EL from this view? How do we move teachers and their instruction to higher levels that integrate social aspects of environmental problems in meaningful, critical ways?

\section{REFERENCES}

Amirshokoohi, A. (2010). Elementary pre-service teachers' environmental literacy and views toward Science, Technology, and Society (STS) issues. Science Educator, 19(1), 56-63.

Ball, D. L., Thames, M. H., Phelps, G., Loewenberg Ball, D., Thames, M. H., \& Phelps, G. (2008). Content knowledge for teaching: What makes it special? Journal of Teacher Education, 59(5), 389-407. https://doi.org/10.1177/0022487 108324554

Berkes, F., Folke, C., \& Colding, J. (Eds.). (2000). Linking social and ecological systems: management practices and social mechanisms for building resilience. Cambridge University Press.

Cheng, I. N. Y., \& So, W. W. M. (2015). Teachers' environmental literacy and teaching - stories of three Hong Kong primary school teachers. International Research in Geographical and Environmental Education, 24(1), 58-79. https://doi.org/10.1080/10382046.2014.967111 
Chua, F. (2016). How do experts and novices think about climate change? Thinking routines as learning and assessment tools. Harvard Univeristy.

Coyle, K. (2005). Environmental Literacy in America. Washington, D.C.

Cutter-Mackenzie, A., \& Smith, R. (2001). Gauging primary school teachers' environmental literacy. Australian Association for Research Education International Education Research Conference, 2(2), 45-60. https://doi.org/10.1007/ BF03026290

Dada, D. O., Eames, C., \& Calder, N. (2017). Impact of environmental education on beginning preservice teachers' environmental literacy. Australian Journal of Environmental Education, 33(3), 201-222. https://doi.org/10.1017/aee.2017.27

Erdogan, M., \& Ok, A. (2011). An assessment of Turkish young pupils' environmental literacy: A nationwide survey. International Journal of Science Education, 33(17), 23752406. https://doi.org/10.1080/09500693.2010.550653

Genc, M., \& Akilli, M. (2016). Modeling the relationships between subdimensions of environmental literacy. Applied Environmental Education and Communication, 15(1), 58-74. https://doi.org/10.1080/1533015X.2016.1141724

Goldman, D., Yavetz, B., \& Pe'er, S. (2014). Student teachers' attainment of environmental literacy in relation to their disciplinary major during undergraduate studies. International Journal of Environmental \& Science Education, 9(4), 369-383.

Gupta, R., Fraser, J., Shane-Simpson, C., Danoff-Burg, S., \& Ardalan, N. (2018). Estimating scale, diversity, and professional training of environmental educators in the U.S. Environmental Education Research, 1-17. https://doi.org/10.1080/13504622.2018.1435778

Hart, P. S. (2011). One or many? The influence of episodic and thematic climate change frames on policy preferences and individual behavior change. Science Communication, 33(1), 28-51. https://doi.org/10.1177/1075547010366400

Hill, H. C., Rowan, B., \& Ball, D. L. (2005). Effects of teachers' mathematical knowledge for teaching on student achievement. American Educational Research Journal, 42(2), 371-406. https://doi.org/10.3102/00028312042002371

Hodgkinson, S. P., \& Innes, J. M. (2001). The Attitudinal influence of career orientation in 1st-year university students: Environmental attitudes as a function of degree choice. The Journal of Environmental Education, 32(3), 3740. https://doi.org/10.1080/00958960109599144

Hollweg, K. S., Taylor, J. R., Bybee, R. W., Marcinkowski, T. J., McBeth, W. C., \& Zoido, P. (2011). Developing a framework for assessing environmental literacy. Washington, DC.

Hsu, S. (2004). Thee ffects of an environmental education program on responsible environmental behavior and associated environmental literacy variables in Taiwanese college students. The Journal of Environmental Education, 35(2), 37-49. https://doi.org/10.3200/JOEE.35.2.37-48
Hsu, S.-J., \& Roth, R. E. (1998). An assessment of environmental literacy and analysis of predictors of responsible environmental behaviour held be secondary teachers in the Hualien area of Taiwan. Environmental Education Research, 4(3), 229-259. https://doi.org/10.1080/ 1350462980040301

Hungerford, H. R., \& Tomera, A. N. (1977). Science in the Elementary School: A Worktext. Stipes.

Iserbyt, P., Ward, P., \& Li, W. (2017). Effects of improved content knowledge on pedagogical content knowledge and student performance in physical education. Physical Education and Sport Pedagogy, 22(1), 71-88. https://doi.org/10.1080/17408989.2015.1095868

Kaplowitz, M. D., \& Levine, R. (2005). How environmental knowledge measures up at a Big Ten university. Environmental Education Research, 11(2), 143-160. https://doi.org/10.1080/1350462042000338324

Kempton, W., \& Holland, D. C. (2003). Identity and sustained environmental practice. In S. D. Clayton, \& S. Opotow (Eds.) Identity and the natural environment: The psychological significance of nature, pp. 317-341. Cambridge: MIT Press.

Lave, J., \& Wenger, E. (1991). Situated learning: Legitimate peripheral participation. Cambridge: Cambridge University Press. https://doi.org/10.1017/CBO9780511815355

Liu, S. Y., Yeh, S. C., Liang, S. W., Fang, W. T., \& Tsai, H. M. (2015). A national investigation of teachers environmental literacy as a reference for promoting environmental education in Taiwan. Journal of Environmental Education, 46(2), 114-132. https://doi.org/10.1080/00958964.2014. 999742

Lloyd-strovas, J., Moseley, C., \& Arsuffi, T. (2018). Environmental literacy of undergraduate college students: Development of the environmental literacy instrument (ELI). School Science and Mathematics, 118, 84-92. https://doi.org/10.1111/ssm.12266

Marcinkowski, T. (1991). The relationship between environmental literacy and responsible environmental behavior in environmental education. Methods and techniques for evaluating environmental education. Paris: UNESCO.

Marcinkowski, T., Shin, D., Noh, K. Negev, M., Sagy, G., Garb, Y., McBeth, B., ... Erdogan, M. (2012). National assessments of environmental literacy: A review, comparison, and analysis. In R. B. Stevenson, M. Brody, J. Dillon, \& A.E.J. Wals (Eds.). International handbook of research on environmental education. New York: Routledge.

McBeth, B., Hungerford, H., Marcinkowski, T., Volk, T., \& Meyers, R. (2011). National Environmental Literacy Assessment, Phase Two: Measuring the Effectiveness of North American Environmental Education Programs with Respect to the Parameters of Environmental Literacy.

McBeth, W., Hungerford, H. R., Marcinkowski, T., Volk, T. L., \& Meyers, R. (2008). National Environmental Literacy Assessment Project: Year 1, National Baseline Study of Middle Grades Students Final Research Report. 
Murphy, T. P., \& Olson, A. M. (2008). The Third Minnesota Report Card on Environmental Literacy: A survey of adult environmental knowledge, attitudes and behavior. St. Paul, MN.

Negev, M., Sagy, G., Garb, Y., Salzberg, A., \& Tal, A. (2008). Evaluating the environmental literacy of Israeli elementary and high school students. The Journal of Environmental Education, 39(2), 3-20. https://doi.org/10.3200/JOEE.39.2. 3-20

Olson, M. E. (1981). Consumers' attitudes toward energy conservation. Journal of Social Issues, 37, 108-131. https://doi.org/10.1111/j.1540-4560.1981.tb02628.x

Orr, D. W. (1992). Ecological literacy: Education and the transition to a postmodern world. Albany: SUNY Press.

Ozsoy, S., Ertepinar, H., \& Saglam, N. (2012). Can eco-schools improve elementary school students' environmental literacy levels? Asia-Pacific Forum on Science Learning and Teaching, 13(2), 1-26.

Roth, C. E. (1968). On the road to conservation. Massachusetts Audubon, (pp. 38-41).

Roth, C. E. (1992). Environmental literacy: Its roots, evolution and directions in the 1990s. Columbus, $\mathrm{OH}$.

Saltan, F., \& Divarci, O. F. (2017). Using blogs to improve elementary school students' environmental literacy in science class. European Journal of Educational Research, 6(3), 347-355. https://doi.org/10.12973/eu-jer.6.3.347

Schultz, P. W. (2002). Inclusion with nature: The psychology of human-nature relations. In W. P. S. Peter Schmuck (Ed.), Psychology of Sustainable Development (pp. 61-78). Boston, MA: Springer. https://doi.org/10.1007/978-1-4615-09950_4

Shin, D., Chu, H., Lee, E., Ko, H., Lee, M., Kang, K., Min, B., \& Park, J. (2005). An assessment of Korean students' environmental literacy. Journal of the Korean Earth Science Society, 26(4), 358-364.

Stables, A. (1998). Environmental Literacy: functional, cultural, critical. The case of the SCAA guidelines. Environmental Education Research, 4(2), 155-164. https://doi.org/10.1080/1350462980040203
Stables, A., \& Bishop, K. (2001). Weak and strong conceptions of environmental literacy: Implications for environmental education. Environmental Education Research, 7(1), 89-97. https://doi.org/10.1080/13504620125643

Stapp, W. B. The concept of environmental education. Environmental Education, 1(1), 30-31. https://doi.org/ 10.1080/00139254.1969.10801479

Stein, D. (1998) Situated learning in adult education. ERIC Digest, (195).

Stern, P. C. (2000). Toward a coherent theory of environmentally significant behavior. Journal of Social Issues, 56(3), 407-424. https://doi.org/10.1111/0022-4537. 00175

Stevenson, K. T., Peterson, M. N., Bondell, H. D., Mertig, A. G., \& Moore, S. E. (2013). Environmental, institutional, and demographic predictors of environmental literacy among middle school children. PLoS ONE, 8(3). https://doi.org/10.1371/journal.pone.0059519

Swanepoel, C. H., Loubser, C. P., \& Chacko, C. P. C. (2002). Measuring the environmental literacy of teachers. South African Journal of Education, 22(4), 282-285.

Taylor, D. (2018). Diversity in Environmental Organizations: Reporting and Transparency (Vol. 1). Ann Arbor, MI.

Tikka, P. M., Kuitunen, M. T., \& Tynys, S. M. (2000). Effects of educational background on students' attitudes, activity levels, and knowledge concerning the environment. The Journal of Environmental Education, 31(3), 12-19. https://doi.org/10.1080/00958960009598640

UNESCO. (1977) The Tbilisi Declaration. An Intergovernmental Conference on Environmental Education (pp. 14-26).

Volk, T. L., Hungerford, H. R., \& Tomera, A. N. (1984). A national survey of curriculum needs as perceived by professional environmental educators. The Journal of Environmental Education, 16(1), 10-19. https://doi.org/ 10.1080/00958964.1984.9942696

Wenger, E. (1999). Communities of practice: Learning, meaning, and identity. Cambridge: Cambridge University Press. https://doi.org/10.1017/CBO9780511803932 